\title{
HUBUNGAN KUALITAS PERAIRAN DENGAN KELIMPAHAN FITOPLANKTON DI PERAIRAN KOEONO, KECAMATAN PALANGGA SELATAN, KABUPATEN KONAWE SELATAN
}

\section{Relationship Quality of Waters with Phitoplankton Abundance in Koeono Waters, Kecamatan Palangga Selatan, Konawe Selatan District}

\author{
Abd Azis ${ }^{1}$, Wa Nurgayah ${ }^{2}$, Salwiyah ${ }^{3}$ \\ ${ }^{1}$ Mahasiswa Jurusan Ilmu Kelautan, \\ Fakultas Perikanan dan Ilmu Kelautan, Universitas Halu Oleo. \\ Jl. H.E.A Mokodompit Kampus Hijau Bumi Tridharma Anduonohu Kendari 93232, Telp/Fax: (0401) 3193782 \\ ${ }^{2}$ Surel: nurgayah_fish@yahoo.com \\ ${ }^{3}$ Surel: wiya_fish@yahoo.com
}

\begin{abstract}
Abstrak
Kelimpahan fitoplankton selalu berubah menyesuaikan dengan kondisi lingkungan hidupnya. Penelitian ini bertujuan untuk menganalisis kelimpahan fitoplankton dan hubungannya dengan kualitas perairan di perairan Koeono Kabupaten Konawe Selatan. Pengambilan data ini dilaksanakan pada bulan Februari- Mei 2019 di tiga stasiun pada kedalam 0,5 m, 5 $\mathrm{m}$, dan $10 \mathrm{~m}$, pengambilan sampel fitoplankton menggunakan plankton net berukuran mata jaring $25 \mu \mathrm{m}$. Hasil penelitian ini menemukan terdapat 31 genera fitoplankton dari 4 kelompok kelas Bacillariophyceae, Cyanophyceae, Dynophyceae dan kelas Coscinodiscophyceae. Kelimpahan fitoplankton di perairan Koeono tertinggi terdapat pada stasiun II pada kedalaman 0,5 m sebesar $281 \mathrm{sel} / \mathrm{L}$ dan terendah terdapat pada stasiun III pada kedalaman $5 \mathrm{~m}$ sebesar $72 \mathrm{sel} / \mathrm{L}$. Hasil Uji Korelasi terhadap perbedaan kelimpahan fitoplankton pada semua stasiun menunjukkan hasil tidak berbeda nyata. Analisis korelasi menunjukkan parameter yang memiliki hubungan kuat dan mempengaruhi kelimpahan fitoplankton adalah DO dan kecerahan dengan tingkat korelasi positif sebesar 0,6192 dan 0,6429. Parameter yang lain seperti salinitas, arus, $\mathrm{pH}$, nitrat dan fosfat tidak memperlihatkan hubungan yang nyata.
\end{abstract}

Kata Kunci: Fitoplankton, Kelimpahan, Kualitas Air, Perairan Desa Koeono

\section{Abstract}

The abundance of phytoplankton always changes according to environmental conditions. This study aims to analyze the abundance phitoplankton and relation to water quality in the waters of Koeono, South Konawe Regency. This research was conducted in February- May 2019 at three stations at $0.5 \mathrm{~m}, 5 \mathrm{~m}$, and $10 \mathrm{~m}$, with sampling using plankton net mesh zised $25 \mu \mathrm{m}$. The results of this study were detected that there were 31 genera of phytoplankton from four classes of Bacillariophyceae, Cyanophyceae, Dynophyceae and the Coscinodiscophyceae class. The highest abundance of phytoplankton in Koeono waters was found at station II at a depth of $0.5 \mathrm{~m}$, wich was 281 cells / L and the lowest was at station III at a depth of $5 \mathrm{~m}$, wich was 72 cells/L. Based on the Correlation Test about differences in the abundance of phytoplankton at all stations is not significantly different. From the results of correlation analysis, parameters that have a strong relation and affect the abundance of phytoplankton are DO and brightness with a positive correlation levels of 0.6192 and 0.6429. Other parameters such as salinity, current, $\mathrm{pH}$, nitrate and phosphate do not show a real relation.

Keywords: Phytoplankton, Abundance, Water Quality, Koeono Waters

\section{Pendahuluan}

Fitoplankton adalah tumbuhan renik yang hidup melayang di perairan dan pergerakannya sangat tergantung pada arus serta memiliki klorofil untuk melakukan fotosintesis.Fitoplankton merupakan sumber kehidupan bagi ekosistem perairan sebab fitoplankton berperan sebagai penghasil makanan atau produsen primer. Keberadaan produsen primer penting karena dapat menunjang kelangsungan hidup organisme air lainnya (Meiriyani dkk., 2011).

$$
\text { Adanya plankton khususnya }
$$

fitoplankton secara kuantiatif dan kualitatif dapat digunakan untuk mengetahui kesuburan suatu perairan, yaitu dengan mengukur kelimpahan dan keanekaragaman jenis fitoplankton di kedalaman perairan tertentu.

Kelimpahan fitoplankton dapat mengasimilasi sebagian besar zat hara dari perairan. Kelimpahan fitoplankton di suatu perairan akan dipengaruhi oleh parameter lingkungan termasuk kualitas perairan dan fisiologi. Kelimpahan dan komposisi fitoplankton dapat berubah pada berbagai tingkatan sebagai respon terhadap 
perubahan kondisi lingkungan fisik, biologi dan kimiawi perairan (Abida, 2010).

Fitoplankton dalam sistem akuatik memerlukan nitrogen dan fospor sebagai faktor pembatas bagi pertumbuhannya, disamping faktor lainnya fitoplankton berhubungan erat dengan nitrat karena nitrat merupakan salah satu senyawa penting dalam sintesa protein hewan dan tumbuhan.Konsentrasi nitrat yang tinggi di suatu perairan dapat menstimulasi pertumbuhan dan perkembangan organisme perairan apabila ada dukungan oleh ketersediaan nutrien.Phospat merupakan faktor penting untuk pertumbuhan fitoplankton dan organisme lainnya. Phospat sangat diperlukan sebagai transfer energi dari luar kedalam sel organisme, karena itu phospat dibutuhkan dalam jumlah yang kecil (sedikit). Phospat merupakan bentuk fosfor yang dapat dimanfaatkan oleh tumbuhan, konsentrasi phospat di perairan jauh lebih kecil dari pada konsentrasi ammonia dan nitrat (Mujiyanto dkk., 2011).

Penilaian kualitas perairan dengan menggunakan pendekatan materi biologi khususnya organisme, fitoplankton akhirakhir ini mulai mendapat perhatian yang besar. Pendekatan biologi sangat bermanfaat, karena tumbuhan tersebut mampu merefleksikan adanya perubahan yang disebabkan oleh sumber daya alam..Kelimpahan fitoplankton dipengaruhi oleh kondisi faktor fisika kimia air karena keberadaannya sangat bergantung pada kondisi perairan.
Perairan Koeono merupakan perairan yang masuk ke dalam wilayah Administratif Kecamatan Palangga Selatan, Kabupaten Konawe Selatan, dimana dikawasan perairan tersebut terdapat adanya tambang nikel sehingga air perairan tersebut sedikit keruh.Air keruh tersebut mempengaruhi organisme dan tumbuhan yang ada di perairan tersebut salah satunya fitoplankton.

Pentingnya kelimpahan dari fitoplankton yang ada di perairan sebagai sumber makanan oleh biota lainnya ini bergantung pada kualitas perairan yang ada.Untuk itu penting adanya penelitian tentang hubungan kualitas perairan dengan kelimpahan fitoplankton di kawasan tersebut. Penelitian ini bertujuan untuk mengetahui kelimpahan fitoplankton pada setiap kedalaman dan mengetahui hubungan parameter kualitas air dengan kelimpahan fitoplankton di Perairan Koeono, Kecamatan Palangga Selatan, Kabupaten Konawe Selatan.

\section{Bahan dan Metode}

Penelitian ini telah dilaksanakan pada bulan Februari- Mei 2019 di Perairan Desa Koeono, Kabupaten Konawe Selatan, Sulawesi Tenggara.Pengambilan sampel dilakukan di lapangan.Analisis sampel dilakukan di Laboratorium Unit Produktivitas dan Lingkungan Perairan, Fakultas Perikanan dan Ilmu Kelautan, Universitas Halu Oleo.Peta lokasi penelitian ini dapat dilihat pada Gambar 1.

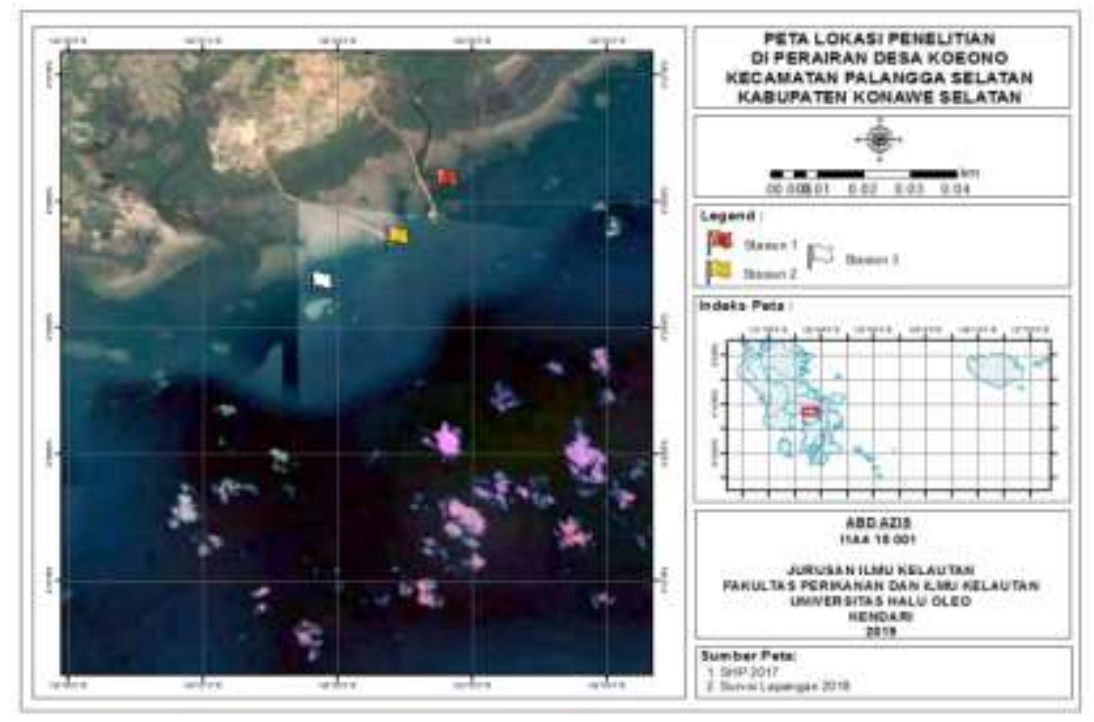

Gambar 1. Peta Lokasi Penelitian Perairan Koeono. 
Pengambilan data fitoplankton dilakukan selama 1 bulan. Pengambilan sampel dilakukan sebanyak 2 kali pengulangan dengan interval waktu pengambilan sampel tiap 1 kali dalam 1 minggu, dengan menggunakan plankton net, berukuran mata jaring $25 \mu \mathrm{m}$. Pengambilan sampel fitoplankton dilakukan pada tiga stasiun dengan kedalaman yang berbeda. Setiap stasiun mempunyai kedalaman yaitu pada kedalaman $0,5 \mathrm{~m}, 5 \mathrm{~m}$, dan $10 \mathrm{~m}$. Pengambilan sampel dilakukan pada pukul 09.00 - 14.00 WITA,

Sampel fitoplankton diambil dengan cara menyaring air yang diambil disetiap kedalaman dengan menggunakan pompa air yang disambungkan dengan pipa yang kemudian diturunkan di kedalaman yang telah ditentukan dengan mengambil sampel air sebanyak 100 liter dengan menggunakan ember volume 10 liter. Hasil penyaringan plankton dimasukkan kedalam botol sampel dengan volume $100 \mathrm{ml}$ dan diberi beberapa tetes lugol, sebanyak 3-4 tetes. Setelah itu sampel diberi label sesuai stasiun, kemudian botol sampel diawetkan dalam coolbox. Setelah itu dibawa ke laboratorium untuk diidentifikasi jenisnya menggunakan mikroskop dengan pembesaran 10-40 x, diidentifikasi menggunakan buku kunci identifikasi Botes (2003), dan Yamaji (1966).

Suhu diukur dengan menggunakan thermometer pada setiap stasiun dengan tiaptiap kedalaman. Pengamatan dengan cara mencelupkan kedalam perairan dan mencatat suhu perairan hasil penunjukan thermometer.

Pengukuran arus dilakukan disetiap stasiun pengamatan.Pengukuran kecepatan arus dilakukan dengan melepas layang-layang arus dengan stopwatch, dan melihat arah arus dengan kompas bidik dengan mengamati pergerakan layang-layang dan mencatatnya. Kecepatan arus diketahui dengan cara menghitung selang waktu (t) yang dibutuhkan layang arus untuk menempuh jarak (s) dengan rumus:

$\mathrm{V}=\mathrm{s} /(\mathrm{t})$

Keterangan :

$\mathrm{V}=$ Kecepatan arus (m/detik)

$\mathrm{s}=$ Jarak tempuh layang-layang $(\mathrm{m})$

$\mathrm{t}=$ Waktu yang digunakan (detik)

Menurunkan secchi disk kedalam air laut.Pada saat jarak antara permukaan air sampai hilangnya warna pada secchi disk atau sampai tidak terlihat dicatat sebagai D1.dan kemudian perlahan-lahan mengangkat secchi disk sampai terlihat kembali sebagai D2. Mencatat hasil pengukuran. Untuk mengukur kecerahan perairan menggunakan rumus berikut:

$\mathrm{N}=(\mathrm{d} 1+\mathrm{d} 2) / 2 \times 100 \%$

Keterangan :

$\mathrm{N}=$ Kecerahan

$\mathrm{d} 1=$ Kedalaman secchi disk saat tidak terlihat

$\mathrm{d} 2$ = kedalaman secchi disk saat mulai tampak kembali

Pengukuran salinitas dengan menggunakan handrefraktometer untuk melihat nilai salinitas suatu perairan yang diukur perkedalaman setiap stasiun. Pengukuran $\mathrm{pH}$ (derajat keasaman) air laut menggunakan $\mathrm{pH}$ indikator dengan perkedalaman setiap stasiun.Caranya yaitu dengan mencelupkan $\mathrm{pH}$ indikator ke air laut lalu mengangkat $\mathrm{pH}$ indikator kemudian mencatat hasilnya. Pengambilan sampel DO menggunakan botol volume $\pm 300 \mathrm{ml}$ yang bersih dan tidak tembus cahaya matahari langsung kemudian saat pengisian di botol hindari terjadinya turbulensi dengan gelembung udara yang masuk ke dalam botol. Pengambilan sampel DO dilakukan disetiap satsiun.

Sampel air untuk analisis nitrat diperoleh dengan mengambil pada setiap kedalaman yang telah ditentukan dari setiap titik stasiun dengan pengambilan sampel di perairan sebanyak 10 liter dengan menggunakan pompa untuk masing- masing stasiun pengamatan, sampel air yang sudah diambil kemudian dimasukkan ke dalam botol sampel ukuran $100 \mathrm{ml}$ dan diawetkan dengan menggunakan $\mathrm{H}_{2} \mathrm{SO}_{4}$ pekat sebanyak $0,5 \mathrm{ml}$ atau sekitar 5 tetes sampai $\mathrm{pH} 2$.

Sampel air untuk analisis ortophospat diperoleh dengan mengambil pada setiap kedalaman yang telah ditentukan dari setiap titik stasiun dengan pengambilan sampel di perairan sebanyak 10 liter dengan menggunakan pompa untuk masing- masing stasiun pengamatan, Sampel air yang sudah diambil disaring menggunakan kertas saring kedalam botol sampel ukuran $100 \mathrm{ml}$. Setelah itu sampel diberi label sesuai stasiun, selanjutnya sampel air dimasukkan ke dalam coolbox untuk kemudian dibawa ke laboratorium untuk dianalisis. Waktu dari pengambilan sampel sampai dianalisis kurang lebih 24 jam, sebelum dianalisis, sampel air setelah dikeluarkan dari coolbox dibiarkan terlebih dahulu sampai kondisi suhunya normal pada suhu kamar antara $26^{\circ} \mathrm{C}-28^{\circ} \mathrm{C}$. 


\section{Analisis Data}

Kelimpahan fitoplankton dihitung dengan metode sensus menggunakan sedwick rafter cell (SRC) yang dihitung berdasarkan formula dari APHA (2005). Yaitu pada persamaan berikut :

$\mathrm{K}=\mathrm{N} /(\mathrm{Ac}) \mathrm{x} \mathrm{At} / \mathrm{Vs} \mathrm{x} \mathrm{Vt} / \mathrm{As}$

Keterangan :

$\mathrm{K}$ = Kelimpahan fitoplankton (sel/L)

$\mathrm{N}=$ Kelimpahan spesies

At $=$ luas penampang permukaan SRC (SRC $=1000)$

$\mathrm{Ac}=$ luas amatan $(\mathrm{SRC}=1000)$

$\mathrm{Vs}=$ Volume air konsentrasi dalam SRC (ml)

$\mathrm{Vt}=$ Volume konsentrasi botol contoh $(\mathrm{ml})$

As $=$ Volume air yang disaring $(\mathrm{L})$

Analisis hubungan digunakan untuk melihat hubungan antara kelimpahan fitoplankton dengan beberapa parameter fisika-kimia perairan.Hubungan tersebut yaitu antara kelimpahan fitoplankton dengan kecerahan, kelimpahan fitoplankton dengan suhu, kelimpahan fitoplankton dengan salinitas, kelimpahan fitoplankton dengan derajat keasaman dan antara kelimpahan fitoplankton dengan arus.Secara statistik hubungan yang umum digunakan adalah sebagai berikut (Sudjana, 2006).

$\mathrm{Y}=\mathrm{a}+\mathrm{bX} 1+\mathrm{bX} 2+\mathrm{bXn}+\ldots+\mathrm{bX} 6$

Keterangan:

$\mathrm{Y}=$ Kelimpahan Fitopankton (sel/L)

$\mathrm{X} 1=$ Suhu

$\mathrm{X} 2=$ Salinitas

$\mathrm{X} 3=$ Kecepatan arus

$\mathrm{X} 4=$ Kecerahan

$\mathrm{X} 5=$ Derajat Keasaman $(\mathrm{pH})$

$\mathrm{X} 6=$ Oksigen terlarut (DO)

$\mathrm{a}=$ konstanta

b1,b2, ...b6 = Koefisien korelasi

Pengolahan data tersebut dilakukan dengan menggunakan Analisis korelasi (Microsoft Excel), antara faktor fisika, kimia terhadap kelimpahan fitoplankton. Menurut Sugiyono (2010), tingkat hubungan nilai Indeks korelasi dinyatakan sebagaimana pada Tabel 1.

Tabel 1. Hubungan nilai indeks korelasi

\begin{tabular}{cc}
\hline Interval & Tingkat \\
Koefisien & Hubungan \\
\hline $0,00-0,199$ & Sangat lemah \\
$0,20-0,399$ & Lemah \\
$0,40-0,599$ & Sedang \\
$0,60-0,799$ & Kuat \\
$0,80-1,00$ & Sangat kuat \\
\hline
\end{tabular}

\section{Hasil dan Pembahasan}

Jenis fitoplankton yang ditemukan di perairan Koeono berjumlah 4 kelas yaitu terdiri dari kelas Bacillariophyceae (18 genera), kelas Dinophyceae (6 genera), kelas Cyanophyceae terdiri dari 1 genera dan kelas Coscinodiscophyceae (6 genera). kelas Bacillariophyceae (18 genera) merupakan fitoplankton dengan jumlah genera tertinggi yang ditemukan. Jenis fitoplankton yang terendah ialah dari kelas Cyanophyceae (1 genera).

Nilai kelimpahan fitoplankton tertinggi terdapat pada stasiun II pada kedalaman $0,5 \mathrm{~m}$ yaitu $281 \mathrm{sel} / \mathrm{L}$ dan terendah terdapat pada stasiun III pada kedalaman $5 \mathrm{~m}$ yaitu $72 \mathrm{sel} / \mathrm{L}$. Tinggi dan rendahnya kelimpahan fitoplankton dipengaruhi oleh perubahan parameter lingkungan. Tingginya kelimpahan fitoplankton terutama di pengaruhi oleh parameter DO dan kecerahan, hal ini terjadi karena nilai DO dan kecerahan memiliki nilai rata-rata tertinggi di stasiun II yang didapatkan dibandingkan pada stasiun I dan III. tingginya kelimpahan fitoplankton dipengaruhi oleh faktor fisika kimia perairan terutama salinitas, DO, kecepatan arus, $\mathrm{pH}$ dan kecerahan, faktor pendukung lainnya nitrat dan phospat (Anwar, 2015).

Kelas Bacillariophyceae yang didapatkan hampir di semua stasiun dan di setiap interval waktu pengambilan sampel, hal ini mengindikasikan bahwa fitoplankton jenis Chaeteceros sp.memiliki penyebaran yang sangat luas. Kelimpahan tertinggi berada pada kedalaman 0,5 meter yakni $281 \mathrm{sel} / \mathrm{L}$ pada stasiun II, kelimpahan Bacillariophyceae yang tertinggi pada perairan Koeono diduga karena jenis ini mampu bertahan hidup pada saat cuaca berubah, kelimpahannya dipengaruhi oleh sifatnya yang kosmopolit (penyebarannya luas) umumnya pada perairan laut (Rosada $d k k ., 2017)$. kelimpahan dari kelas Bacillariophyceae dari golongan fitoplankton umunya masih tergolong berlimpah ditemukan di laut meskipun dalam kondisi cuaca yang berubah-ubah (Nontji, 2008). 
Tabel 2. Jenis fitoplankton yang ditemukan selama periode penelitian

\begin{tabular}{|c|c|c|c|c|}
\hline No & Kelas & Ordo & Family & Genus \\
\hline \multirow[t]{17}{*}{1} & Bacillariophyceae & Bacillariales & $\begin{array}{l}\text { Chaetoceraceae } \\
\text { Chaetoceraceae }\end{array}$ & $\begin{array}{l}\text { Chaetoceros sp. } \\
\text { Bacteriastrum }\end{array}$ \\
\hline & & Mastogloiales & Achnanthaceae & Achnanthes \\
\hline & & Pennales & Nitzschiaceae & Nitzschia sp. \\
\hline & & & Nitzschiaceae & Pseudo-Nitzschia \\
\hline & & & Tabellariaceae & Diatoma \\
\hline & & & Tabellariaceae & Tabellaria \\
\hline & & & Fragilariaceae & Synedra \\
\hline & & Eunotiales & Eunotiaceae & Eunotia \\
\hline & & & Thallassiosiraceae & Cyclotella \\
\hline & & & Thallassiosiraceae & Thalasiosira \\
\hline & & Thalassionematales & Thalassionemataceae & Thalassionema \\
\hline & & & Thalassionemataceae & Planktoniella \\
\hline & & Biddulphiales & Biddulphiaceae & Biddulphia \\
\hline & & Naviculales & Amphipleuraceae & Amphiprora \\
\hline & & & Pleurosigmataceae & Pleurosigma \\
\hline & & & Naviculaceae & Navicula \\
\hline & & Licmophorales & Licmophoraceae & Licmophora \\
\hline \multirow[t]{6}{*}{2} & Dinophyceae & Peridiniales & Peridiniaceae & Peridinium \\
\hline & & & Peridiniaceae & Scrippsiella \\
\hline & & Gymnodiniales & Gymnodiniaceae & Gymnodinium \\
\hline & & & Protoperidiniaceae & Protoperidinium \\
\hline & & Dinophysiales & Dinophysiaceae & Dinophysis \\
\hline & & Gonyaulacales & Ceratiaceae & Ceratium \\
\hline 3 & Cyanophyceae & Osscillatoriales & Osscillatoriales & Oscillatoria \\
\hline \multirow[t]{6}{*}{4} & Coscinodiscophyceae & Coscinodiscales & Coscinodiscaceae & Coscinodiscus \\
\hline & & Lithodesmiales & Lithodesmiaceae & Ditylum \\
\hline & & Stephanopyxales & Stephanopyxidaceae & Stephanopsis \\
\hline & & Centrales & Rhizosoleniaceae & Rhizosolenia \\
\hline & & Rhizosoleniales & Rhizosoleniaceae & Urosolenia \\
\hline & & Melosirales & Melosiraceae & Mellosira \\
\hline
\end{tabular}

Kelimpahan fitoplankton berdasarkan kedalaman menunjukan kelas Bacillariophyceae melimpah disetiap kedalaman karena hampir semua jenis ditemukan menyebar di setiap stasiun. Tingginya kelimpahan fitoplankton dari kelas Bacillariophyceae diduga karena kelas tersebut memiliki kemampuan reproduksi yang lebih besar dibandingkan kelompok lainnya pada saat terjadi peningkatan konsentrasi zat hara, diatom mampu melakukan pembelahan mitosis sebanyak tiga kali dalam 24 jam (Faturohman $d k k .$, 2016). Dinoflagellata hanya mampu melakukan satu kali dalam 24 jam pada kondisi zat hara yng sama.
Hal ini seperti yang dikemukakan (Nurfadilla, dkk. 2012), bahwa kelas Bacillariophyceae merupakan jenis fitoplankton yang paling toleran dan mampu beradaptasi dengan baik pada lingkungan perairan, selain itu Bacillariophyceae memiliki kemampuanreproduksi yang lebih besar dibandingkan fitoplankton lainnya.

Kelas Bacillariophyceae merupakan kelompok yang mendominasi di setiap stasiun, baik dari komposisi jumlah jenis $(>80 \%)$ maupun kelimpahan (>90\%). Fitoplankton yang umum terdapat di laut biasanya berukuran besar dan terdiri dari dua kelompok yang mendominasi, yaitu 
diatom (kelas Bacillariophyceae) dan dinoflagelata (Wulandari, 2015).

Hasil pengukuran oksigen terlarut (DO) pada keempat stasiun menunjukkan kisaran antara 6,10 - 6,75 mg/L, dimana nilai DO tertinggi berada di stasiun II sebesar $6,75 \mathrm{mg} / \mathrm{L}$ dan terendah pada stasiun III sebesar $6,10 \mathrm{mg} / \mathrm{L}$. Nilai ini masih dalam kisaran baku mutu menurut Kepmen - LH (2004) yaitu >5 mg/L. Nilai ini juga sesuai dengan tingkat kelimpahan fitoplankton pada setiap stasiun penelitian, dimana pada kelimpahan fitoplankton yang tinggi menghasilkan oksigen yang lebih banyak dibandingkan dengan kelimpahan fitoplankton yang lebih rendah. Ini terjadi karena oksigen terlarut merupakan produksi dari hasil fotosintesis (Rimper, 2002).

Kelas Cyanophyceae merupakan kelas paling jarang dijumpai serta memiliki kelimpahan terendah, rendahnya kelimpahan Cyanophyceae disebabkan oleh kelas Cyanophyceae tidak memiliki kemampuan toleransi yang luas terhadap kondisi lingkungan.Hal ini sejalan dengan pernyataan AryawatidanThoha (2011), umumnya kelas Cyanophyceae kurang toleran terhadap perubahan salinitas.Nilai salinitas yang terukur pada setiap stasiun pengamatan berkisar antara $31-33 \%$. Nilai salinitas tersebut hampir sama pada setiap stasiun pengamatan, Hal ini terjadi karena pengaruh air tawar dari daratan pada stasiun I. Variasi salinitas dapat menentukan kelimpahan dan distribusi fitoplankton (Hariyati $d k k$.,2010). Salinitas merupakan salah satu parameter yang menentukan jenis-jenis fitoplankton yang terdapat dalam suatu perairan, tergantung dari sifat fitoplankton tersebut apakah eurihalin (organisme tanaman atau hewan yang dapat beradaptasi dengan kadar salinitas) atau stenohalin (organisme yang hanya dapat beradaptasi dengan sedikit perubahan salinitas) Sumartini $d k k$., (2013). Secara umum, salinitas permukaan perairan laut di Indonesia rata-rata berkisar antara 32-34 \%o (Endang $d k k$., 2013).

Nilai kelimpahan terendah berada pada kedalaman $5 \mathrm{~m}$ yakni $72 \mathrm{sel} / \mathrm{L}$ pada stasiun III, rendahnya nilai kelimpahan pada kedalaman $5 \mathrm{~m}$ disebabkan olehfakor kecepatan arus. Hal ini berkaitan dengan nilai kecepatan arus yang diperoleh selama penelitian dilakukan antara 0.08- 0.3 $\mathrm{m} /$ det. Kecepatan arus mempengaruhi kelimpahan fitoplankton. Hal ini didukung oleh Lasri $d k k$., (2013) menyatakan bahwa kecepatan arus merupakan parameter penting sehubungan dengan keberadaan fitoplankton, arus yang kencang dapat memengaruhi distribusi fitoplankton pada suatu perairan maka secara tidak langsung juga berpengaruh terhadap kelimpahan fitoplankton.

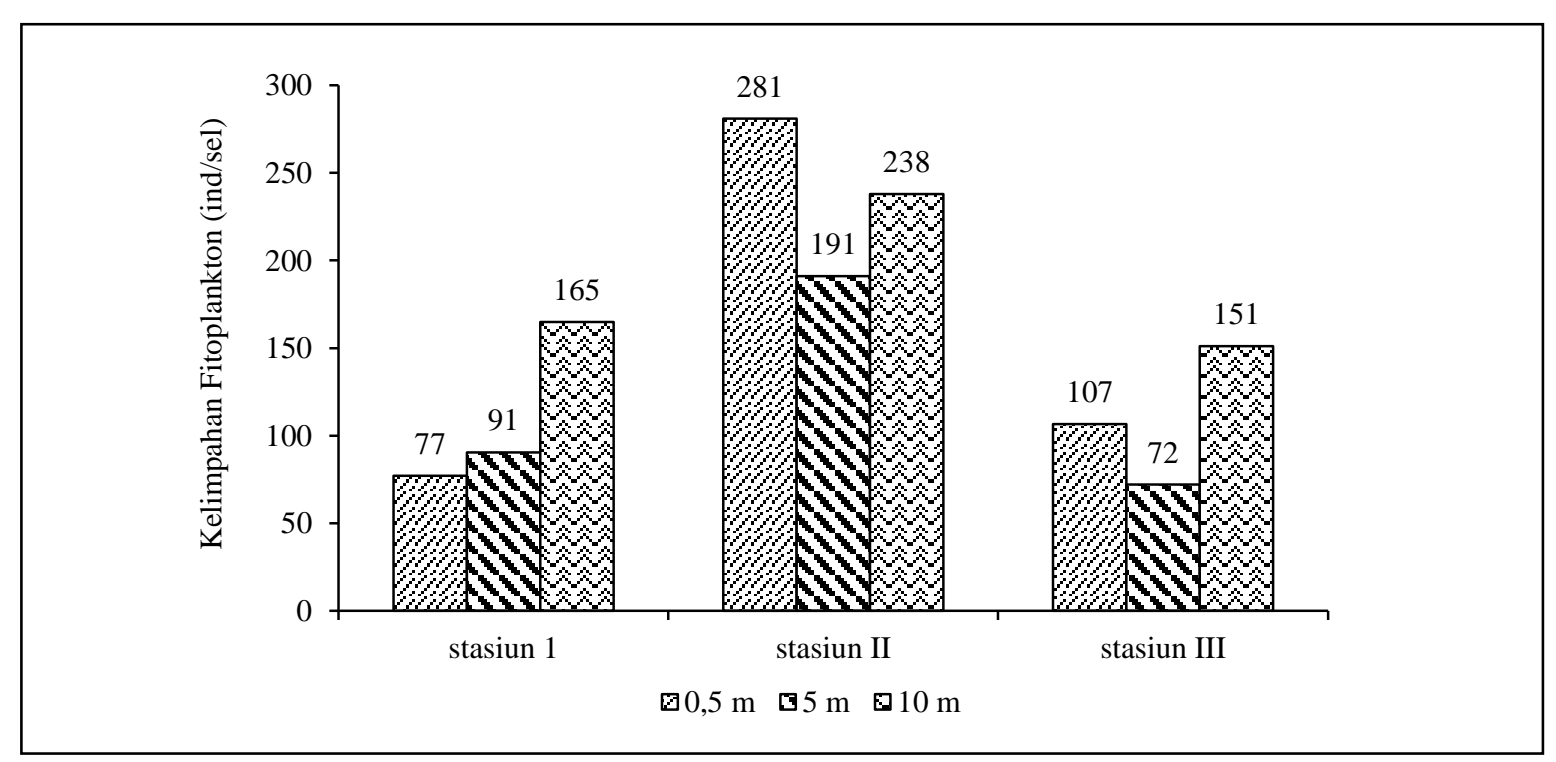

Gambar 2. Kelimpahan Fitoplankton di Perairan Koeono 
Tabel 3. Parameter fisika dan kimia perairan

\begin{tabular}{|c|c|c|c|c|c|}
\hline \multirow[t]{2}{*}{ No } & \multirow[t]{2}{*}{ Parameter } & \multirow{2}{*}{ Kedalaman (m) } & \multicolumn{3}{|c|}{ Stasiun } \\
\hline & & & I & II & III \\
\hline \multirow[t]{3}{*}{1} & Nitrat $(\mathrm{mg} / \mathrm{L})$ & 0.5 & 0.049 & 0.050 & 0.040 \\
\hline & & 5 & 0.044 & 0.038 & 0.036 \\
\hline & & 10 & 0.045 & 0.035 & 0.046 \\
\hline \multirow[t]{3}{*}{2} & Ortophosfat (mg/L) & 0.5 & 0.0025 & 0.0017 & 0.0018 \\
\hline & & 5 & 0.0017 & 0.0032 & 0.0021 \\
\hline & & 10 & 0.0024 & 0.0030 & 0.0022 \\
\hline \multirow[t]{3}{*}{3} & Suhu $\left(\mathrm{C}^{\circ}\right)$ & 0.5 & 31 & 32 & 30.5 \\
\hline & & 5 & 30 & 29 & 28.5 \\
\hline & & 10 & 29 & 28 & 28 \\
\hline \multirow[t]{3}{*}{4} & Kecerahan $(\%)$ & 0.5 & 100 & 100 & 100 \\
\hline & & 5 & 100 & 100 & 100 \\
\hline & & 10 & 100 & 100 & 100 \\
\hline \multirow[t]{3}{*}{5} & Kecepatan Arus (m/detik) & 0,5 & 0.3 & 0.04 & 0.08 \\
\hline & & 5 & 0.2 & 0.08 & 0.07 \\
\hline & & 10 & 0.3 & 0.07 & 0.07 \\
\hline \multirow[t]{3}{*}{$\overline{6}$} & $\overline{\mathrm{pH}}$ & 0,5 & 6.5 & 7 & 7 \\
\hline & & 5 & 6.5 & 7 & 7 \\
\hline & & 10 & 6.5 & 7 & 7 \\
\hline \multirow[t]{3}{*}{7} & DO (ppm) & 0,5 & 6.55 & 6.75 & 6.2 \\
\hline & & 5 & 6.5 & 6.35 & 6.1 \\
\hline & & 10 & 6.2 & 6.75 & 6.4 \\
\hline \multirow[t]{3}{*}{8} & Salinitas (ppt) & 0,5 & 32.5 & 33 & 32.5 \\
\hline & & 5 & 31.5 & 32 & 31.5 \\
\hline & & 10 & 31 & 31 & 31 \\
\hline
\end{tabular}

Nilai kelimpahan terendah berada pada kedalaman 5 meter yakni $72 \mathrm{sel} / \mathrm{L}$ pada stasiun III, rendahnya nilai kelimpahan pada kedalaman 5 meter disebabkan rendahnya penetrasi cahaya yang masuk ke dalam perairan. Hal ini berkaitan dengan nilai kecerahan yang diperoleh selama penelitian dilakukan antara $0,5-10$ meter kedalaman yaitu $100 \%$, nilai kecerahan tersebut sangat baik untuk kehidupan fitoplankton, sebab tingginya kecerahan suatu perairan akan menyebabkan nilai intensitas cahaya yang masuk ke dalam suatu perairan akan meningkat, hal ini sesuai dengan pendapat Salwiyah (2010) kecerahan merupakan salah satu faktor pembatas bagi kehidupan fitoplankton karena mempengaruhi penetrasi cahaya yang masuk ke dalam perairan. Tingginya nilai kecerahan di Perairan Koeono diduga karena kurangnya zat-zat terlarut dalam perairan yang dapat mempengaruhi kecerahan.
Suhu perairan yang normal yaitu berkisar antara $28-30^{\circ} \mathrm{C}$ juga memengaruhi kelimpahan fitoplankton. Hal ini sesuai dengan pernyataan Ambiasa (2007) bahwa suhu air yang baik bagi kelangsungan hidup dan perkembangan plankton berkisar antara $20-30^{\circ} \mathrm{C}$. Menurut Manigasi (2013), suhu perairan memengaruhi keberadaan fitoplankton secara fisiologis dan ekologis. Secara fisiologis perbedaan suhu perairan sangat berpengaruh terhadap ukuran fitoplankton. Secara ekologis, perubahan suhu menyebabkan perbedaan komposisi dan kelimpahan fitoplankton.Dari Tabel 5 terlihat bahwa suhu di lokasi penelitian berkisar antara $28-32{ }^{\circ} \mathrm{C}$. Nilai suhu pada keempat stasiun tersebut relatif sama dan tidak menunjukkan adanya perbedaan walaupun terdapat variasi dalam kisaran yang sempit. Hal ini dikarenakan keadaan cuaca pada saat pengukuran suhu relatif sama sehingga suhu tidak mengalami 
perubahan atau fluktuasi. Secara umum kisaran suhu yang diperoleh selama penelitian merupakan kisaran yang masih dapat mendukung kehidupan fitoplankton. Kisaran suhu ini sesuai dengan pernyataan Nontji (1993) yang mengemukakan bahwa suhu perairan Nusantara umumnya berkisar antara 28 - $32^{\circ} \mathrm{C}$.Sedangkan kisaran suhu yang optimum bagi pertumbuhan fitoplankton di perairan berkisar antara $20-30^{\circ} \mathrm{C}$ (Effendi, 2003).Suhu dilokasi penelitian masih termasuk dalam kisaran tersebut.

Nilai pH yang terukur di lokasi penelitian berkisar antara 6,5 - 7. Nilai pH ini masih dalam kategori baik untuk pertumbuhan fitoplankton. Menurut
Syam (2002), perairan dengan $\mathrm{pH}$ antara 6 - 9 merupakan perairan dengan kesuburan yang tinggi dan tergolong produktif karena memiliki kisaran $\mathrm{pH}$ yang dapat mendorong proses pembongkaran bahan organik yang ada dalam perairan menjadi mineral-mineral yang dapat diasimilasikan oleh fitoplankton. $\mathrm{pH}$ air yang memenuhi syarat untuk kehidupan organismefitoplankton berkisar antara 6,58. Perubahan $\mathrm{pH}$ badan air sangat menganggu kehidupan tumbuhan, hewan dan organisme pengurai yang hidup di dalam badan air tersebut (Burhanuddin, 2015).pH optimum untuk kehidupan fitoplankton berkisar antara 5,5-8,5 (Junaedi, $d k k$., 2018).

Tabel 4. Hasil analisis nilai korelasi kualitas perairan dengan kelimpahan fitopankton

\begin{tabular}{|c|c|c|c|c|c|c|c|}
\hline \multirow{2}{*}{ No } & \multirow{2}{*}{ Parameter } & \multirow{2}{*}{$\begin{array}{c}\text { Kedalaman } \\
\text { (m) }\end{array}$} & \multicolumn{3}{|c|}{ Stasiun } & \multirow{2}{*}{$\begin{array}{c}\text { Nilai } \\
\text { Korelasi }\end{array}$} & \multirow{2}{*}{$\begin{array}{c}\text { Tingkat } \\
\text { Hubungan }\end{array}$} \\
\hline & & & I & II & III & & \\
\hline \multirow[t]{3}{*}{1} & Nitrat (mg/l) & 0.5 & 0.049 & 0.050 & 0.0395 & & \\
\hline & & 5 & 0.044 & 0.038 & 0.036 & & \\
\hline & & 10 & 0.045 & 0.035 & 0.0455 & 0.078 & Sangat Lemah \\
\hline \multirow[t]{3}{*}{2} & $\begin{array}{l}\text { Ortophosfat } \\
(\mathrm{mo} / \mathrm{l})\end{array}$ & 0.5 & 0.003 & 0.0018 & 0.0018 & & \\
\hline & & 5 & 0.0017 & 0.0032 & 0.0021 & & \\
\hline & & 10 & 0.0024 & 0.0030 & 0.0022 & 0.288 & Lemah \\
\hline \multirow[t]{3}{*}{3} & Suhu $\left(C^{\circ}\right)$ & 0.5 & 31 & 32 & 30.5 & & \\
\hline & & 5 & 30 & 29 & 28.5 & & \\
\hline & & 10 & 29 & 28 & 28 & 0.072 & Sangat Lemah \\
\hline \multirow[t]{3}{*}{4} & $\begin{array}{l}\text { Kecerahan } \\
(\%)\end{array}$ & 0.5 & 100 & 100 & 100 & & \\
\hline & & 5 & 100 & 100 & 100 & & \\
\hline & & 10 & 100 & 100 & 100 & 0.643 & Kuat \\
\hline \multirow[t]{4}{*}{5} & Kecepatan & 05 & & & & & \\
\hline & Arus (m/det) & 0,5 & 0.3 & 0.04 & 0.08 & & \\
\hline & & 5 & 0.2 & 0.08 & 0.07 & & \\
\hline & & 10 & 0.3 & 0.07 & 0.07 & -0.397 & Sangat Lemah \\
\hline \multirow[t]{3}{*}{6} & $\mathrm{pH}$ & 0,5 & 6.5 & 7 & 7 & & \\
\hline & & 5 & 6.5 & 7 & 7 & & \\
\hline & & 10 & 6.5 & 7 & 7 & 0.423 & Sedang \\
\hline \multirow[t]{3}{*}{7} & DO (ppm) & 0,5 & 6.55 & 6.75 & 6.20 & & \\
\hline & & 5 & 6.50 & 6.35 & 6.10 & & \\
\hline & & 10 & 6.20 & 6.75 & 6.40 & 0.619 & Kuat \\
\hline \multirow[t]{3}{*}{8} & Salinitas (ppt) & 0,5 & 32.5 & 33 & 32.5 & & \\
\hline & & 5 & 31.5 & 32 & 31.5 & & \\
\hline & & 10 & 31 & 31 & 31 & 0.095 & Sangat Lemah \\
\hline \multirow[t]{3}{*}{9} & Kelimpahan & 0,5 & 77 & 281 & 107 & & \\
\hline & & 5 & 91 & 191 & 72 & & \\
\hline & & 10 & 165 & 238 & 151 & & \\
\hline
\end{tabular}


Faktor $\mathrm{N}$ dan $\mathrm{P}$ sangat mempengaruhi kehidupan fitoplankton didalam suatu perairan karena berperan penting dalam proses fotosintesis yang dilakukan oleh organisme fitoplankton tersebut. Kelimpahan komunitas fitoplankton diperairan sangat berhubungan dengan kandungan nutrien seperti phospat, nitrat, dan hara lainnya.Kandungan nutrien dapat mempengaruhi kelimpahan fitoplankton dan sebaliknya fitoplankton yang dapat menurunkan kandungan nutrien dalam air. Hal ini sesuai apa yang dikemukakan Alianto danDamar(2016) yang mengatakan bahwa konsentrasi suhu, salinitas, dan unsur hara (nitrat, phospat dan silikat) secara statistik terkait dengan distribusi komunitas fitoplankton yang berbeda.

Kandungan nitrat yang ditemukan pada setiap stasiun pengamatan berkisar antara $0,035-0,050 \mathrm{mg} / \mathrm{L}$. Dari kisaran nilai yang didapatkan kondisi kandungan nitrat perairan Koeono disebut perairan oligotrofik, hal ini didukung dengan pernyataan (Tanjung,2014) bahwa tingkat kesuburan perairan berdasarkan kandungan nitrat $0,01-0,25 \mathrm{mg} / \mathrm{L}$ disebut perairan oligotrofik (kesuburan lemah), 0,26-0,50 $\mathrm{mg} / \mathrm{L}$ disebut perairan mesotrofik (kesuburan sedang) dan diatas 0,51-0,75 $\mathrm{mg} / \mathrm{L}$ disebut perairan eutrofik (kesuburan tinggi).

Namun Sverdrup et al. dalam Hermana (2007) menyatakan bahwa kisaran nitrat di laut adalah $1-600 \mu \mathrm{g} / \mathrm{l}$. Jika dikonversikan maka konsentrasi nitrat yang diperoleh masih termasuk kedalam kisaran tersebut yaitu $64,6-88,2 \mu \mathrm{g} / 1 . P a d a$ penelitian yang dilakukan Nielsen et al. (2002) memperlihatkan pola peningkatan nutrien menyebabkan peningkatan populasi fitoplankton, dan penurunan nutrien menyebabkan pula penurunan populasi fitoplankton. Tetapi kisaran tersebut cukup rendah untuk pertumbuhan fitoplankton, dimana menurut Pratiwi (2015) menyatakan bahwa kandungan nitrat yang optimum untuk pertumbuhan fitoplankton berkisar antara $0,9-3,5 \mathrm{mg} / \mathrm{L}$ dan akan menjadi faktor pembatas apabila kurang dari 0,44 mg/L, dan menurut Prowsedalam Basmi (2000) menyatakan bahwa pertumbuhan optimal fitoplankton terjadi bila kandungan nitrat dalam air 3,9 $-15,5 \mathrm{mg} / \mathrm{L}$.

Ortophosfat merupakan unsur yang penting terutama bagi pertumbuhan fitoplankton. Hasil pengukuran Ortophosfat pada setiap stasiun pengamatan berkisar antara 0,0017 $0,0032 \mathrm{mg} / \mathrm{L}$, dimana nilai Ortophosfat tertinggi berada pada stasiun II sebesar $0,0032 \mathrm{mg} / \mathrm{L}$ dan nilai Ortophosfat terendah pada stasiun I sebesar $0,0017 \mathrm{mg} / \mathrm{L}$. Nilai ini menurut Kepmen - LH (2004) menandakan bahwa Orthofosfat di perairan Koeono dibawah standar baku mutu air laut untuk biota laut yaitu $0,015 \mathrm{mg} / \mathrm{L}$. Kondisi tersebut mendukung atau tidak berbahaya bagi biota laut yang hidup di perairan Koeono.

Secara umum kadar Orthofosfat ratarata di perairan Koeono berkisar antara $0,0017-0,0032 \mathrm{mg} / \mathrm{L}$, menunjukkan bahwa perairan ini cukup subur. Joshimura dan Wardoyo dalam Patty, dkk.,(2015) mengklasifikasikan tingkat kesuburan perairan yang cukup subur berdasarkan kadar Orthofosfat berkisar antara 0,0021$0,050 \mathrm{mg} / \mathrm{L}$ dan perairan yang subur berkisar antara 0,051-0,100 mg/L.

Nilai korelasi Ortophospat yang didapatkan yaitu $0,287 \mathrm{mg} / \mathrm{L}$ bahwa nilai kandungan Ortophospat masih mendukung kehidupan fitoplankton dan belum jadi faktor pembatas, hal ini sesuai dengan pernyataan Junaedi (2018) bahwa kandungan Ortophospat bagi yang optimum bagi pertumbuhan fitoplankton berkisar 0,27-5,51 mg/L, jika kandungan kurang dari $0,02 \mathrm{mg} / \mathrm{L}$ maka akan menjadi faktor pembatas. Sesuai pendapat Burhanuddin (2015) menetapkan suatu nilai Ortophospat sebesar $2,8 \mathrm{mg} / \mathrm{L}$ sebagai batas air yang tidak tercemar.

Tingginya nilai Ortophospat pada stasiun II, hal ini diduga karena tingginya sedimen yang berasal dari kegiatan penambangan yang mengakibatkan jatuhnya sedimen hasil penambangan 
ketika terjadinya hujan. Sedimen merupakan tempat penyimpanan Ortophospat dalam siklus yang terjadi di laut. Senyawa Ortophospat yang terikat di sedimen dapat mengalami dekomposisi dengan bantuan bakteri maupun melalui proses abiotik menghasilkan senyawa Ortophospat terlarut yang dapat mengalami difusi kembali ke kolom perairan (Endang $d k k ., 2013)$. Hal ini dapat dipahami karena proses-proses yang terjadi di sekitar perairan dengan kegiatan penambangan terjadi yang menghasilkan sedimen serta berbagai aktivitas masyarakat yang menghasilkan limbah yang dapat mengkhayakan Ortophospat.

Ditinjau dari nilai kelimpahan yang diperoleh pada penelitian yang telah dilakukan jika dilihat secara total nilai kelimpahan dapat dikategorikan belum melimpah (sedang). Hal ini sesuai dengan pernyataan Sumartini (2013) yang mengatakan suatu populasi fitoplankton baru dapat dikatakan melimpah, bila kelimpahan suatu spesies fitoplankton mencapai nilai $2 \times 10^{9} \mathrm{sel} / \mathrm{L}$.

Untuk menggambarkan hubungan antara kelimpahan fitoplankton dengan kualitas air, maka harus dilakukan uji korelasi. Terdapat dua parameter yang berpengaruh secara nyata terhadap tingkat kelimpahan fitoplankton yaitu, DO dan kecerahan yang berhubungan secara positif terhadap tingkat kelimpahan fitoplankton, sedangkan variabel kecepatan arus berpengaruh secara negatif terhadap tingkat kelimpahan fitoplankton. Untuk parameter suhu, salinitas, ortophosfat, nitrat dan $\mathrm{pH}$ diperoleh nilai korelasi> 0,05 yang artinya perubahan parameter suhu, salinitas, ortophosfat, nitrat dan $\mathrm{pH}$ tidak berpengaruh nyataterhadap tingkat kelimpahan fitoplankton di perairan Koeono. Berdasarkan tingkat pengaruh yang paling kuat adalah oksigen terlarut dan kecerahan dengan nilai korelasi 0,619 dan 0,642 pada tingkat kepercayaan $95 \%$.

Tingkat hubungan yang kuat antara DO dengan nilai kelimpahan fitoplankton mengindikasikan bahwa kandungan oksigen begitu berhubungan dengan adanya laju pertumbuhan fitoplankton. Hal ini didukung dengan pernyataan Siregar (2010) bahwa, tingginya kandungan oksigen di perairan merupakan hasil difusi oksigen dari udara bebas dan hasil dari proses fotosentesis fitoplankton.

Dari hasil diatas, dapat diartikan bahwa setiap kenaikan sebesar satu satuan suhu perairan, kelimpahan fitoplankton akan mengalami peningkatan sebesar 0,072 satuan dengan asumsi parameter lainnya bersifat tetap.Dari hasil pengukuran suhu tersebut (Tabel 4) menunjukkan suhu perairan cenderung tinggi karena pada saat pengukuran cuaca dalam keadaan terik dan cerah, suhu yang terlalu tinggi juga akan mempengaruhi pertumbuhan fitoplankton di perairan. Fitoplankton umumnya dapat hidup pada kisaran suhu $25-30{ }^{0} \mathrm{C}$ namun kondisi yang optimal adalah berkisar $25{ }^{0} \mathrm{C}$ karena pada kondisi tersebut beberapa jenis fitoplankton melakukan produktifitas optimal. Hal ini sesuai dengan pendapat Asih (2014) suhu optimum untuk pertumbuhan plankton berkisar antara 25 $32{ }^{\circ} \mathrm{C}$, dengan demikian kondisi suhu perairan Koeono masih layak untuk kehidupan fitoplankton.

Kondisi hubungan antara kelimpahan fitoplankton terhadap salinitas memperlihatkan hubungan positif. Tingginya salinitas pada perairan Koeono mencapai 33 ppm diakibatkan karena tingginya suhu perairan sehingga terjadi penguapan. Hal ini sesuai pernyataan Syalihin (2015) bahwa, Kelimpahan fitoplankton akan mengalami kenaikan jika salinitas turun mencirikan bahwa salinitas sudah terlalu tinggi untuk kehidupan beberapa jenis fitoplankton yang ada di perairan Koeono tidak memiliki adaptasi yang luas terhadap perubahan salinitas.

Sifat hubungan korelasi antara salinitas dengan nilai kelimpahan fitoplankton di perairan Koeono yaitu 0.095 dan bersifat positif (+) artinya, semakin rendah nilai salinitas diikuti dengan nilai kelimpahan fitoplankton 
yang rendah, dan sebaliknya jika nilai salinitas semakin tinggi maka kelimpahan plankton akan semakin tinggi. Menurut Pratiwi (2015) salinitas, suhu, cahaya dan ketersediaan nutrisi merupakan faktor penting bagi distribusi fitoplankton.

Hubungan korelasi antara kecerahan dengan kelimpahan fitoplankton memperlihatkan hubungan yang kuat.Nilai korelasi kecerahan yang didapatkan yaitu 0,642 memperlihatkan hubungan yang kuat berdasarkan indeks korelasi menurut Sugiyono (2010) pada Tabel 2.Kecerahan pada suatu perairan berhubungan erat dengan kedalaman. Perairan dengan kecerahan yang baik akan memberi pengaruh yang baik terhadap daya tembus sinar matahari yang dapat berguna bagi proses fotosintesis fitoplankton. Hal ini sesuai dengan Fachrul (2007) yang menyatakan bahwa semakin dalam penetrasi cahaya kedalam perairan menyebabkan semakin besar daerah dimana proses fotosintesis dapat berlangsung.

Setiap kenaikan satu satuan kecerahan perairan, kelimpahan fitoplankton akan mengalami peningkatan sebesar 0,642 satuan dengan asumsi parameter lain bersifat tetap. Salanjutnya setiap kenaikan sebesar satu satuan kecepatan arus perairan Koeono maka kelimpahan fitoplankton akan mengalami penurunan sebesar $-0,397$ satuan dengan asumsi parameter lainnya bersifat tetap. Dengan demikian kelimpahan fitoplankton akan mengalami peningkatan pada arus yang cukup lemah, karena fitoplankton akan terbawa tersebar kebadan perairan bila arus perairan terlalu kuat. Hal ini didukung pernyataan Ma'arif (2018) bahwa, Jika arus terlalu deras akan mengakibatkan kekeruhan perairan yang tinggi yang mempengaruhi tingkat kecerahan dan mempengaruhi fotosintesis optimal.

Untuk parameter kimia, kondisi derajat keasaman perairan menunjukkan nilai hubungan yang positif. Dapat disimpulkan bahwa setiap kenaikan satu satuan derajat keasaman akan menyebabkan peningkatan kelimpahan sebesar 0,44 satuan dengan asumsi parameter lain bersifat tetap. Untuk oksigen terlarut setiap peningkatannya sebesar satu satuan akan meningkatkan kelimpahan fitoplankton sebesar 0,619 ppm satuan dengan asumsi parameter lainnya tetap. Terlihat jelas bahwa diantara beberapa parameter tersebut, oksigen terlarut yang memiliki hubungan positif tinggi terhadap kelimpahan fitoplankton.

Kandungan unsur hara di suatu perairan pada umumnya berkaitan dengan kelimpahan fitoplankton di perairan tersebut (Yuliana, 2014).Kandungan unsur hara nitrat dan phospat sangat mempengaruhi keberadaan fitoplankton. Selama pengamatan, kandungan unsur hara diperoleh memiliki fluktuasi nilai konsentrasi yang seiring dengan kelimpahan fitoplankton. Hal ini diduga disebabkan unsur hara tersebut dimanfaatkan dengan baik untuk pertumbuhan fitoplankton walaupun perairan tersebut termasuk dalam kondisi perairan yang tercemar limbah. Menurut Suparjo (2007) kelimpahan komunitas fitoplankton sangat berhubungan dengan kandungan nutrien seperti phospat, nitrat, silikat, dan hara lainnya.Kandungan nutrien dapat mempengaruhi kelimpahan fitoplankton dan sebaliknya fitoplankton yang padat dapat menurunkan kandungan nutrien dalam air.Perubahan komposisi fitoplankton selanjutnya dapat mempengaruhi komposisi fitoplankton dan komunitas plankton secara keseluruhan dalam suatu ekosistem.

Hubungan antara konsentrasi nitrat terhadap kelimpahan fitoplankton sangat lemah. Hal ini dapat dilihat dari nilai korelasi 0,0778. Sangat lemahnya hubungan nitrat terhadap kelimpahan fitoplankton dapat disebabkan oleh berbagai faktor diantaranya yaitu faktor fisika dan kimia perairan yaitu suhu, kecerahan, salinitas, $\mathrm{pH}$ dan DO.Hal ini 
sesuai pernyataan Ramayana (2007) bahwa kelimpahan fitoplankton dipengaruhi oleh konsentrasi nitrat dan phospat yaitu jika konsentrasi nitrat dan phospat rendah maka kelimpahan fitoplankton tinggi, demikian pula sebaliknya.Hal ini terjadi karena fitoplankton memanfaatkan nitrat dan phospat untuk pertumbuhan optimumnya dan memanfaatkannya untuk fotosintesis. Dimana setiap genus fitoplankton kebutuhan akan nitrat dan phospat berbeda-beda.

Berdasarkan hasil analisa data penelitian yang diperoleh nilai korelasi Ortophosfat sebesar $0,287 \mathrm{mg} / \mathrm{L}$, hubungan Ortophosfat dengan fitoplankton tergolong lemah menurut Sugiyono (2010) tingkat hubungan interval korelasi dengan nilai 0,20-0,399 tergolong lemah. Sedangkan nilai korelasi antara nitrat dan kelimpahan fitoplankton sebesar 0,0778 tingkat hubungan indeks korelasi menurut Sugiyono (2010) yaitu tergolong sangat lemah karena dibawah nilai 0,199. Dapat disimpulkan bahwa kondisi unsur hara pada perairan koeono masih mendukung kehidupan organisme tumbuhan fitoplankton dan belum menjadi faktor pembatas.

Korelasi yang sangat lemah antara kelimpahan fitoplankton dengan Orthophospat pada masing-masing kedalaman, hal ini menjelaskan bahwa semakin tinggi kelimpahan fitoplankton akan diikuti dengan rendahnya nilai Orthophospat, sebaliknya jika kelimpahan fitoplankton semakin rendah, akan diikuti dengan tingginya nilai Orthophospat. Rendahnya nilai Orthophospat pada suatu perairan, hal ini mengindikasikan bahwa nutrien tersebut telah digunakan oleh fitoplankton untuk tumbuh dan berkembang.Hal ini didukung dengan pernyataan Suryani (2013), bahwa fitoplankton memiliki daya asorbsi yang tinggi terhadap nutrien Orthophospat pada bagian permukaan perairan.

\section{Simpulan}

Adapun kesimpulan pada penelitian ini adalah sebagai berikut:

1. Kelimpahan fitoplankton di perairan Koeono tertinggi terdapat pada stasiun II pada kedalaman $0,5 \mathrm{~m}$ yaitu 281 $\mathrm{sel} / \mathrm{L}$ dan terendah terdapat pada stasiun III pada kedalaman $5 \mathrm{~m}$ yaitu 72 sel/L. Tinggi dan rendahnya kelimpahan fitoplankton dipengaruhi oleh perubahan parameter lingkungan.

2. Hubungan kualitas air terhadap kelimpahan fitoplankton di perairan koeono kecamatan palangga selatan yang berhubungan paling kuat adalah parameter kecerahan dan DO dari nilai korelasi 0,619 dan 0,642.

\section{Daftar Pustaka}

Abida, I. W. 2010. Struktur Komunitas dan Kelimpahan Fitoplankton di Perairan Muara Sungai Porong Sidoarjo. Jurnal Kelautan Vol. 3(1) Hal: 36-40.

Anwar, N. 2008.Karateristik Fisika Kimia Perairan dan Kaitannya dengan Distribusi serta Kelimpahan Larva Ikan di Teluk Pelabuhan Ratu. Sekolah Pascasarjana IPB. Bogor.

Anwar, A. 2015. Studi Kelimpahan dan Sebaran Phytoplankton Secara Vertikal di Pesisir Perairan Kuricadd. Makassar. Jurnal Balik Diwa. Vol. 6 (2) Hal: 3440

APHA.2005. Standar Methods for Examination of Water and Wastewater. New York.

Ardiyansyah, K. 2017. Hubungan Nitrat dan Fosfat Terhadap Kelimpahan Fitoplankton di Perairan Pulau Anak Krakatau.Lampung. Skripsi. Hal: 9-39

Asih Widi Wisudawati, E. S. 2014. Metode Pembelajaran IPA. Jakarta. Bumi Aksara.

Botes, L. 2003. Phytoplankton Identification Catalogue (Globallast Monograph Series No. 7). Programme Coordination Unit, global Ballast Water Management programme. Saldanha bay. South Africa.

Effendi, H. 2003.Telaah Kualitas Air Bagi Pengelolaan Sumberdaya Hayati Lingkungan

Perairan.Kanysius.Yogyakarta. 
Faturohman, I., Sunarto, Nurruhwati, I. 2016. Korelasi Kelimpahan Plankton dengan Suhu Perairan Laut di Sekitar PLTU Cirebon. Jurnal Perikanan Kelautan. Vol. VII No.1 : 115-122.

Endang, Y. H., Sartimbul A., dan Khsanah I. R. 2013. Kelimpahan dan Keanekaragaman Plankton di Perairan Selat Bali. Jurnal Ilmu Kelautan 18(4):193-202

Hermana, A. 2007.Sebaran Fitoplankton di Perairan Selatan Jawa dan Selatan Nusa Tenggara Indonesia (CRUISE SO-184 RV.SONNE). Departemen Manajemen Sumberdaya Perairan. Fakultas Perikanan dan Ilmu Kelautan.Institut Pertanian Bogor. Bogor.

Junaedi, E., Abidin, Z., dan Novasaraseta N. 2018. Keanekaragaman Phytoplankton di Situ Balong Kambang Desa Pasawahan Kecamatan Pasawahan Kabupaten Kuningan. Jurnal Quagga, 10 (1): 33

Kep MENLH. 2004. Keputusan Kantor Menteri Negara LingkunganHidup No.Kep 51 / MENLH / I / 2004. TentangPedomanPenetap an Baku MutuLingkungan.11 hal.

Ma'arif, C., M. 2018.Perbandingan Keanekaragaman dan Kelimpahan Plankton Pada Ekosistem Terumbu Karang Alami dengan Terumbu Buatan di Perairan Pasir Putih Situbondo.Skripsi. UIN Sunan Ampel, Surabaya.

Meiriyani, F., T Z Ulqodry, T. Z.,Putri, W. A. E., 2011., Komposisi dan Sebaran Fitoplankton di Perairan Muara Sungai Way Belau, Bandar Lampung. Maspari Journal. 03 (2011) Hal : 69-77

Nontji, A. 2008.Plankton Laut.LIPI. Jakarta.

Odum, E.P. 1994. Dasar-Dasar Ekologi (Terjemahan). Gajah Mada University. Yogyakarta.477 Hlm.

Patten,P. V. 2010. Dasar-Dasar Ekologi Edisi Ketiga. Yogyakarta. Gadjah Mada University Press.

Patty S. I., Arfah H., dan Abdul, M. S. 2015. Zat Hara (Fosfat, Nitrat), Oksigen Terlarut dan $\mathrm{Ph}$ Kaitannya Dengan Kesuburan di Perairan Jikumerasa, Pulau Buru. Jurnal Pesisir dan Laut Tropis. Vol 1(1): 43-51

Pratiwi, D. E., 2015. Hubungan Kelimpahan Plankton Terhadap Kualitas Air di
Perairan Malang Rapat Kabupaten Bintan Provinsi Kepulauan Riau.Jurnal Pesisir dan Laut Tropis. Hal: 1-13

Ramayana, S. 2007. Hubungan Konsentrasi Nitrat dan Posfat Terhadap Kelimpahan Fitoplankton Pada Areal Pertambakan di Desa Wadonggo Kecamatan Tinanggea Sulawesi Tenggara. Skripsi. Kendari. Hal: 23

Rimper, J., 2002. Kelimpahan Phytoplankton dan Kondisi Hydroseanografi Perairan Teluk Manado. Makalah Pengantar Falsafah Sains Pasca Sarjana S3 IPB. Bogor. http://tumoutou.net/702_05123/ joice_rimper.h tm

Rosada, K K., Sunardi, dan Pribadi T, Putri S A., 2017. Struktur Komunitas Fitoplankton pada Berbagai Kedalaman di Pantai Timur Pananjung Pangandaran. Jurnal Biodjati 2 (I) : 3037. Universitas Padjadjaran. Sumedang. Salwiyah.2010. Kondisi Kualitas Air Sehubungan Dengan Kesuburan Perairan Sekitar PLTU NII Tanasa Kabupaten Konawe Provinsi Sulawesi Tenggara. WartaWiptek.Vol. 18.No.2. Hal: 52-57.

Siregar.M.H. 2010. Keanekaragaman Plankton di Hulu Sungai Asahan, Porsea. Skripsi. Universitas Sumatera Utara. Medan.

Sumartini, S., Rudiyanti S., dan Suryanti. 2013. Kualitas Perairan Sungai Seketak Semarang Berdasarkan Komposisi dan Kelimpahan Fitoplankton. JOURNAL OF MANAGEMENT OF AQUATIC RESOURCES. Vol. 2 (2); 38-45

Suryani, E. 2013. Keanekaragaman Zooplankton di Perairan Pantai Lekok Kabupaten Pasuruan. Skripsi. Fakultas Sains dan Teknologi.UIN Maulana Malik Ibrahim. Malang. $75 \mathrm{hlm}$.

Syam, A.R. 2002. Produktivitas Primer Fitoplankton dan Perbandingan Beberapa Karakteristik Biofisikimia Perairan Teluk Jakarta dan Teluk Lampung.Program Pascasarjana.IPB. Bogor. 128 hal.

Syalihin.2015. Struktur Komunitas Fitoplankton di Perairan Muara sungai Dompak Kota Tanjungpinang. Skripsi.Universitas Maritim Raja Ali Haji. Tanjungpinang 
Wulandari, Y. D. 2015. Struktur Komunitas Fitoplankton dan Tingkat Kesuburan Perairan Pesisir Tangerang. Skripsi, Institute Pertanian Bogor.

Yamaji, E. E. 1966. Illustration Of The Marine Plankton Of Japan. Hoikusha, Osaka Japan.

Yuliana, 2014. Keterkaitan Antara Kelimpahan Zooplankton dengan Fitoplankton dan Parameter FisikaKimia di Perairan Jailolo, Halmahera Barat. Maspari Journal,Vol. 6 (1) ; 2531 